\title{
Ownership Structure and Corporate Voluntary Disclosures in Transition Economy*
}

\author{
Mofijul Hoq MASUM ${ }^{1}$, Ahmed Razman Abdul LATIFF², Mohammad Noor Hisham OSMAN ${ }^{3}$
}

Received: July 25, 2020 Revised: August 23, 2020 Accepted: September 09, 2020

\begin{abstract}
The study aims to investigate the impact of ownership structure on corporate voluntary disclosure in the listed companies of Bangladesh. While many studies on the impact of ownership structure on voluntary disclosure have looked at developed and developing countries, few studies have been carried out in a transition economy. Using a three-step relative voluntary disclosure index, the study applies a multivariate analysis on the cross-sectional data for the year 2018. The findings indicate that the quality of voluntary disclosure in transition economy is still below average but has improved compared to findings from the previous literature. We found a significant inverse relationship between corporate voluntary disclosure and public ownership, while no significant relationships between voluntary disclosure and institutional ownership, director ownership, and foreign ownership have been found. The empirical findings of the study will provide evidence to promote the voluntary disclosure characterized by the ownership structures. The findings have important implications for both local and foreign investors as they make their investment decisions especially related to a transition economy. Besides, the findings will assist, not only the corporate executives in rearranging their reporting paradigm, but also the regulators and governments in similar transition economy in adopting and formulating their corporate policies and strategies.
\end{abstract}

Keywords: Voluntary Disclosures, Ownership Structure, Agency Theory, Legitimacy Theory

JEL Classification Code: M41, G14, G30

\section{Introduction}

In recent times, financial shambles have elicited more scepticism regarding the quality of financial information publicly disclosed by the business organization (Kolsi, 2017).

\footnotetext{
*Acknowledgements:

We are very thankful to the Institute of Advanced Research (IAR), United International University, Bangladesh to grant us the fund by mobilizing which we generate our required data for this empirical study.

${ }^{1}$ First Author and Corresponding Author. Assistant Professor, School of Business \& Economics, United International University, Dhaka, Bangladesh [Postal Address: United City, Madani Avenue, Badda, Dhaka, 1212, Bangladesh] Email: masum@bus.uiu.ac.bd

${ }^{2}$ Associate Professor, Putra Business School, Malaysia.

Email: razman@putrabs.edu.my

${ }^{3}$ Senior Lecturer, Faculty of Management and Economics, Universiti

Putra Malaysia, Malaysia. Email: mhisham@upm.edu.my

(c) Copyright: The Author(s)

This is an Open Access article distributed under the terms of the Creative Commons Attribution Non-Commercial License (https://creativecommons.org/licenses/by-nc/4.0/) which permits unrestricted non-commercial use, distribution, and reproduction in any medium, provided the original work is properly cited.
}

Indeed, disclosing sophisticated information by the business entities may reduce both information asymmetry and agency problems. Voluntary disclosure is one of the most popular communication tools through which the business entity can lessen the information asymmetry between existing and potential investors and organization itself (Akhtaruddin \& Haron, 2010; Healy \& Palepu, 2001; Jiang, Habib, \& Hu, 2011; Madi, Ishak, \& Manaf, 2014). Accordingly, providing more financial and non-financial information voluntarily, the organization may induce the potential investors to invest more (Al Maskati \& Hamdan, 2017). Consecutively, the availability of more private information of the business entity gradually reduce the agency costs and enhancing the transparency in corporate reporting (Akhtaruddin \& Haron, 2010; Madi et al., 2014). Transparency in corporate reporting and disclosing more information to the public also protect the minority shareholders as well (Jiang et al., 2011; Li, Mangena, \& Pike, 2012). Nowadays, information plays a very crucial role and the availability of more information also portrays the organizations' long-term growth and corporate sustainability (Abeysekera \& Guthrie, 2005; Deegan, 2002). Moreover, disclosing the private information of the 
business entity may increase the reputation of the business (Abeysekera \& Guthrie, 2005; Khanna \& Liao, 2014) and attract prospective investors (Samaha et al., 2015). We extend this literature by accommodating the antecedents and consequences of corporate voluntary disclosures both financial and non-financial pertaining to the ownership structure in a transition economy - Bangladesh.

Bangladesh is in the process of becoming a developing country as it complies with three conditions set up by the United Nation, namely, Gross National Income (GNI) s per capita, Human Assets Index (HAI) and Economic Vulnerability Index (EVI) (Bhattacharya, 2018). A country undergoing this process is considered to be in a transition economy. Bangladesh has been recognized as a developing country in the early April 2018, both economically and socially, by United Nations Economic and Social Council (UNESC) (Trade \& Development, 2019). Although, Bangladesh has met all three required criteria to become a developing country, the country must sustain the progress for at least six years to graduate from the least developing country to the developing country. The announcement will be effective from 2024. During this transition period from 2018 to 2024 the economic structure of the country has to be transformed from an aid-based country to a trade-based country (Bhattacharya, 2018). Thus, it becomes a tremendous challenge for both the corporate people and the government of a transition economy to retain the existing investors and to attract prospective investors both local and foreign. In this context, voluntary disclosure may contribute significantly. Thus, it is very important for both the investors and the regulatory bodies in a transition economy to understand the role of owner's structure in disclosing more voluntary information that will help them in optimizating decisionmaking.

The quality of corporate disclosure in Bangladesh is very poor (Belal et al., 2013) although the quality of corporate disclosure is improving in recent years (Masum et al., 2019). Masum et al. (2019) conducted an empirical study to explore the corporate voluntary climate-change reporting and found that most of the companies have incredibly low scores on climate reporting; except a few, most of them have score below average. Yet, some of the listed companies have scores of zero, which indicates that some of the listed companies do not disclose any climate-change information publicly although the country is one of the most environmentallyjeopardized countries of the world. Masum et al. (2019) also conducted another study based on various dimensions of corporate social responsibility (CSR) disclosures of the listed companies of Bangladesh and found that those listed companies are disclosing more information voluntarily concerning the employee-related CSR and society-related CSR rather environmental CSR, product CSR and customer
CSR. But the literature is yet to investigate the roles of ownership structures in corporate voluntary disclosures.

The objective of the study is to explore the influence of ownership structure on the corporate voluntary disclosure in a transition economy such as Bangladesh, to have a deeper understanding, and apply the concepts of agency theory and legitimacy theory. The study is unique as it examines for the first time the impact of ownership structure in corporate disclosure in an economy being transformed from the least developing country to developing country. Moreover, the study is unique in that it describes the ownership structure in view of the wide range of shareholdings. In addition, the voluntary disclosure is a composite variable of nine broad dimensions, which is unique in the literature on both voluntary disclosure and transition economy - Bangladesh. Finally, the study is unique as the composition of voluntary disclosure index is derived from a combination of the academic literature and the criteria of the United Nations. The remaining of the study is organized as follows: first, we review the literature on corporate voluntary disclosures and ownership structures to derive the hypotheses in line with the theory. Then, we define our sample construction, disclosure index construction, operationalization of variables, and model specification. Finally, we discuss our results and draw conclusion, their implications, and the study limitations and directions for future research.

\section{Literature Review and Hypothesis Development}

Lately, corporate voluntary disclosure becomes one of the most important issues in corporate reporting all over the world (Elfeky, 2017; Kamel \& Awadallah, 2017; Kolsi, 2017; Zaini, Samkin, Sharma, \& Davey, 2018). Voluntary reporting is the reporting of corporate information by the business organization beyond their mandatory reporting (Dhaliwal et al., 2011). Voluntary disclosure is not only a communication tool (Madi et al., 2014), but also a tool to enhance the reputation of the company (Abeysekera \& Guthrie, 2005), and a tool to attract prospective investors (Samaha et al., 2015). In addition, agency theory postulates that the demand for disclosing more voluntary information becomes pivotal due to agency conflicts between insiders of the business and other core stakeholders (Jensen \& Meckling, 1976). This wide range of corporate voluntary information is very useful for the investors because it diminishes frauds and earnings manipulation (Kolsi, 2017). An et al. (2011) postulates that agency theory may explain information asymmetry and the principal-agent relationship as well as relationship with the other stakeholders. Moreover, a business organization expects to legitimize operational activities to disclose voluntary information (Branco \& Rodrigues, 2008). As per the concept 
of legitimacy theory, the actions of the business organization are desirable within the set of norms, values, and beliefs automatically established within the society (Suchman, 1995). Hence, the legitimacy theory assumes a social contract between the society and the business organization at which the business is itself legitimized to provide information to all the members of the society (Cormier \& Gordon, 2001). From the above discussion, there appears a congruence between the agency theory and the legitimacy theory in the literature of corporate voluntary disclosure.

\subsection{Effect of Institutional Ownership on Corporate Voluntary Disclosure}

Institutional ownership or shareholding is a shareholding that has extremely large amount of shares (Elfeky, 2017). Institutional ownership is a common characteristic in developing country as they are perceived as an efficient response to considerable institutional emptiness due to shaky institutions and the impoverished infrastructure in these countries (Elango et al., 2016). As per the context of agency theory, where business entities have dispersed ownership, that is where many investors have small chunks of shares on a particular company, companies will disclose more information to satisfy wider interest of the diversified investors (Marston \& Polei, 2004). Conversely, institutional investors may gain the required confidential information of the company through direct communication with the company (Kolsi, 2017). Thus, an inverse relationship between the institutional ownership and voluntary disclosure is anticipated. From the perspective of legitimacy theory, the business, as part of the contract with the society, is legitimized to disclose information to the society (Cormier \& Gordon, 2001). On the contrary, institutional shareholders may get access to the information of the company internally (Elfeky, 2017), which hampers the availability of the information to the minor shareholders as they have less bargaining power. Empirical studies in developed countries pointed to the positive association between institutional ownership and corporate voluntary disclosures such as in Finland (Schadewitz \& Blevins, 1998), Australia (Mitchell et al., 1995) and Germany (Marston \& Polei, 2004), while mixed findings were found in the developing countries (Kolsi, 2017; Nguyen et al., 2020). Aljifri et al., (2014) found a positive association between institutional ownership and corporate disclosures subject to the condition that the institutional holdings ranged between $5 \%$ to $10 \%$ of the total equity. Elfeky (2017) in Egypt found negative association between them. Likewise, Kolsi (2017) in Abu Dhabi obtained the same findings, while Kolsi (2012) found no significant association between them in Tunisia. Based on these inconclusive results and arguments from the aforementioned theories, we formulate our first hypothesis as:
H1: Institutional ownership has significant negative association with corporate voluntary disclosures

\subsection{Effect of Directors Ownership on Corporate Voluntary Disclosure}

Directors of the business entity in a developing economy control core operations of an organization and progressively perform a vital role in establishing rules to generate norms of the discretionary reporting behaviors of the organization (Masum \& Khan, 2019). Directors' ownership may have possible impact on corporate voluntary disclosure (Ghazali \& Weetman, 2006; Sarhan \& Ntim, 2019). From the context of agency theory, directors' ownership may remove agency conflicts between directors and other shareholders by harmonizing their base of interest (Lilienfeld-Toal \& Ruenzi, 2014; Pillai \& Al-Malkawi, 2018). In addition, the board members of the business entities do not put too much effort to increase the level of corporate voluntary disclosure (Alnabsha et al., 2018; Sarhan \& Ntim, 2019). Likewise, from the context of legitimacy theory, firms having a lower proportion of directors shareholding typically put more concentration in voluntary disclosure with the aim of improving the corporate legitimacy and gaining the confidence of the shareholders (Ghazali \& Weetman, 2006). Previous studies on the association between directors' ownership and corporate voluntary disclosure were inconclusive. For instance, Albitar (2015) and Khlif, Ahmed et al. (2017) found negative association between board ownership and corporate voluntary disclosures, while Alnabsha et al. (2018) and Samaha et al. (2015) found significant association between them. From the above review, we state the following hypothesis:

H2: Director ownership has significant negative association with the corporate voluntary disclosures.

\subsection{Effect of Public Ownership on Corporate Voluntary Disclosure}

Public ownership or general shareholding is defined as the proportion of shares held by the dispersed level of shareholders inside the organization. Because of the lack of sophisticated institutional development and poor legal protections of the dispersed shareholders in a developing economy (Bhuiyan \& Masum, 2010; Lodh et al., 2014), the concept of agency theory states that disclosing more information will reduce the information asymmetry among the different types of shareholders (Donnelly \& Mulcahy, 2008; Jensen \& Meckling, 1976), thus, the agency problems is being minimized (Al-Bassam et al., 2018; Ntim \& Soobaroyen, 2013). From the perspective of legitimacy theory, corporate voluntary disclosure may enhance the congruence of corporate 
vision and mission along with the norms, values, and beliefs in the society through providing a wide range of information (Sarhan et al., 2019). The structures of legitimacy theory may vary as the basis of organization's legitimacy may vary according to the country context, community context, and attitude context (Belal et al., 2013; Bhuyan, 2018; Deegan et al., 2000). Since the public shareholdings include the minority holdings, they have less bargaining power to compel the board to disclose more information. Practically, the bigger the public shareholdings, the less likely the disclosure of information of the corporations. Based on the above discussion, our third hypothesis is derived as follows:

H3: Public ownership has significant negative association with corporate voluntary disclosures.

\subsection{Effect of Foreign Ownership on Corporate Voluntary Disclosure}

The extent of corporate voluntary disclosure is improving in developing countries like Bangladesh due to the pressure exerted by the foreign investors (Islam \& Deegan, 2008). Companies in developing countries have a tendency to disclose more information voluntarily, while dealing with multinational companies as a way to enhance their reputation and satisfying the expectations of investors, particularly on the international issues like child labor, impoverished working atmosphere and abasement of human rights (Zaini et al., 2018). From the agency theory perspective, Aljifri et al. (2014) postulated that corporate voluntary disclosure was expected to be better in widely dispersed firm. Accordingly, the requirements of information by the foreign investors were expected to be higher because of the remoteness of the geographical location between managers and owners (Kolsi, 2017). Empirical studies on corporate disclosures also postulate that dissemination of ownership is an important issue in corporate disclosures (Hossain, Lin, \& Adams, 1994). From the perspective of agency theory, companies having foreign investors tend to provide more information publicly, thus reduce the information asymmetry (Jensen \& Meckling, 1976). Kolsi (2017) conducted an empirical study based on the Abu Dhabi Securities Exchange and found that foreign listing positively influences the corporate voluntary disclosures. Based on the above arguments and theoretical concepts, we formulate a fourth hypothesis:

H4: Foreign ownership has significant positive association with the corporate voluntary disclosures.

\section{Methodology}

\subsection{Sample Construction}

The study entails a sample of 98 DSE-listed nonfinancial companies in 2018. We ignore the banking, insurance and financial industries due to their customized regulations and distinct capital structures that may impinge on their corporate disclosures and practices (Elmagrhi et al., 2017). The selection of one year is acceptable as there is a tendency of disclosing the same extent of corporate disclosure policy over time (Botosan, 1997; Masum et al., 2019). Meanwhile, we select the year 2018 because, at the beginning of this year, Bangladesh enters in transition economy when it graduated from the least developing country to a developing country. With regards to the final sample construction, we select annual reports of 98 companies for the study due to the unavailability of the annual report or un-audited report of companies being $\mathrm{Z}$ category-classified by the DSE as they neither call regular AGM nor declare dividends regularly, and we did not include companies having the end of financial year other than June 30. Audited annual reports have been selected as the source of secondary data as they are more reliable and relevant to portray the financial and non-financial pictures of a company(Masum et al., 2019). Moreover, annual reports are publicly available. The detail of sample construction is presented on Table1.

Table 1: Final sample construction

\begin{tabular}{|l|c|}
\hline Description & Number of Companies \\
\hline Initial samples & $(100)$ \\
\hline Less: Bank, insurance and financial institutions & $(12)$ \\
\hline Less: Companies having un-audited annual reports in 2018 & $(52)$ \\
\hline Less: Companies having only financial statements & $(34)$ \\
\hline Less: Companies having unavailable annual reports in DSE & $(10)$ \\
\hline Less: Companies having another year end than June 30 & $(12)$ \\
\hline Less: Companies in Z category & 98 \\
\hline Final Sample & \\
\hline
\end{tabular}


Table 2: Disclosure index construction

\begin{tabular}{|l|l|c|l|}
\hline Category & \multicolumn{1}{|c|}{ Titles of category } & Total items & \multicolumn{1}{|c|}{ References } \\
\hline 1 & $\begin{array}{l}\text { General corporate and strategic } \\
\text { information disclosure }\end{array}$ & 12 & $\begin{array}{l}\text { Alnabasha et al., 2018; Kamel \& Awadallah, } \\
\text { 2017; Elfeky, 2017. }\end{array}$ \\
\hline 2 & $\begin{array}{l}\text { Corporate governance information } \\
\text { disclosure }\end{array}$ & 14 & $\begin{array}{l}\text { Alnabasha et al., 2018; Kamel \& Awadallah, } \\
\text { 2017; Sarhan et al., 2019. }\end{array}$ \\
\hline 3 & Climate Change information disclosure & 12 & Choi., 2010, Masum et al., 2019 \\
\hline 4 & Environmental disclosures & 13 & $\begin{array}{l}\text { Sarhan et al., 2019; Islam and Deegan 2010; } \\
\text { Kolsi, 2017. }\end{array}$ \\
\hline 5 & Energy information disclosures & 8 & Islam and Deegan 2010; Masum et al., 2019. \\
\hline 6 & Employee related disclosures & 16 & $\begin{array}{l}\text { Islam and Deegan 2010; Kolsi, 2017; Kamel \& } \\
\text { Awadallah, 2017; Elfeky, 2017 }\end{array}$ \\
\hline 7 & Social information disclosure & 8 & $\begin{array}{l}\text { Elfeky, 2017; Islam and Deegan 2010; Kolsi, } \\
\text { 2017. }\end{array}$ \\
\hline 8 & Product information disclosure & 4 & $\begin{array}{l}\text { Islam and Deegan 2010; Kolsi, 2017; Kamel \& } \\
\text { Awadallah, 2017 }\end{array}$ \\
\hline 9 & Customer information disclosure & 5 & Kamel \& Awadallah, 2017; Elfeky, 2017 \\
\hline
\end{tabular}

\subsection{Construction of Disclosure Index}

The disclosure index used in the study is determined according to the process developed by Botosan (1997). A three-step procedure has been applied to determine the disclosure index. Firstly, the total number of items disclosed as voluntary disclosures of business entity are counted along with their relevance. Secondly, we assign 1 for every disclosed item, otherwise 0 for that particular item. Thirdly, we used a relative score for each company through scaling the actual score of each company by the total scores. The following formula is used to determine the voluntary disclosure score:

$$
\text { VD_SCORE }=\sum_{i=2018}^{n j} x i j / n j
$$

Where, is the maximum possible score of company $\mathrm{j}$. Thus, for the study, maximum possible score for $n j$ will be ninetytwo. However, the total number of disclosure items of the study is classified into nine subsections and total of 92 content items - all of which are taken from the reviewed literature. While most of the previous studies adopt a particular disclosure index, in this study, we have used a combined approach to select the items of disclosure as all the items are not relevant in the context of the transition economy, a detail shown in Table 2. And Xij is the total actual items disclosed by firm $\mathrm{j}$ for the period 2018.

\subsection{Operationalization of Variables and Model Specification}

In the study, we classify the selected variables into three categories, namely, dependent variables - voluntary disclosures, and four proxy variables for the independent variables - institutional ownership, director ownership, public ownership, and foreign ownership; four control variables are used. Details of the variable measurements are presented in Table 3. We use a number of control variables as they may have influence on the corporate voluntary disclosures (Al-Bassam et al., 2018; Kolsi, 2017). In Table 3, we present details of the endogenous variables and the set of exogeneous variables stemming from hypothesis development along with their label. The following multiple regression model is employed to test the hypotheses derived from the literature:

$$
\begin{aligned}
& V D S=\alpha+\beta 1 I N S \_O W N+\beta 2 D I R \_O W N+\beta 3 P U B \\
& O W N+\beta 4 \text { FOR_OWN }+\beta 5 F I R \_A G E \overline{+} \beta 6 \text { FIR_SIZ }+\beta \overline{7} \\
& F I R \_L E V+\beta 8 F I R \_R O A+\varepsilon
\end{aligned}
$$

\section{Results and Discussion}

\subsection{Descriptive Statistics}

Table 4 presents the descriptive analysis of the dependent variable, independent variables and control variables. The table shows that the mean voluntary disclosure score is $29.68 \%$, while the minimum voluntary disclosure score is $9.78 \%$ and the maximum score is $63.04 \%$ with a standard deviation of $12.28 \%$. These findings depict the wide range of variations in the corporate disclosures of the listed companies in Bangladesh. These findings are also consistent with the recent literature on voluntary disclosures (Masum et al., 2019), but the level of corporate disclosures is improving from the last two decades (Belal, 2000; Belal et al., 2013). From the disclosure context, it becomes obvious that the investors in a transition economy only obtain very few information - around $30 \%$ from the annual report and the rest from other sources. 
Table 3: Operationalization of variables

\begin{tabular}{|c|c|c|c|}
\hline Variables & Label & Description & References \\
\hline $\begin{array}{l}\text { Score on voluntary } \\
\text { disclosure }\end{array}$ & VDS & $\begin{array}{l}\text { Dichotomous variables - one for each } \\
\text { disclosing item otherwise zero. }\end{array}$ & $\begin{array}{l}\text { Botosan, 1997; Elfeky, 2017; Kolsi, } \\
2017\end{array}$ \\
\hline Institutional ownership & INS_OWN & $\begin{array}{l}\text { Total number of institutional shareholdings } \\
\text { scaled by total shareholding. }\end{array}$ & Kolsi, 2017; Elfeky, 2017 \\
\hline Directors ownership & DIR_OWN & $\begin{array}{l}\text { Total number of directors' shareholdings } \\
\text { scaled by total shareholding. }\end{array}$ & Sarhan et al., 2019 \\
\hline Public ownership & PUB_OWN & $\begin{array}{l}\text { Total number of minority or ordinary } \\
\text { shareholdings scaled by total } \\
\text { shareholding. }\end{array}$ & Sarhan et al., 2019 \\
\hline Foreign ownership & FOR_OWN & $\begin{array}{l}\text { Total number of foreign shareholdings } \\
\text { scaled by total shareholding. }\end{array}$ & Kolsi, 2017 \\
\hline Firm age & FIR_AGE & $\begin{array}{l}\text { Differences between the date of } \\
\text { establishment and the sampling frame- } \\
\text { the year } 2018 \text {. }\end{array}$ & Kolsi, 2017; Sarhan et al., 2019 \\
\hline Firm size & FIR_SIZ & Natural logarithm of firm's total assets & $\begin{array}{l}\text { Kolsi, 2017; Elfeky, 2017; Kamel } \\
\text { and Awadallah, 2017; Sarhan et al., } \\
2019\end{array}$ \\
\hline Firm leverage & FIR_LEV & Total debt scaled by total equity. & $\begin{array}{l}\text { Kolsi, 2017; Elfeky, 2017; Kamel } \\
\text { and Awadallah, 2017; Sarhan et al., } \\
2019\end{array}$ \\
\hline $\begin{array}{l}\text { Firm profitability- } \\
\text { return on asset }\end{array}$ & FIR_ROA & $\begin{array}{l}\text { Reported net profit scaled by total assets } \\
\text { of the company }\end{array}$ & $\begin{array}{l}\text { Kolsi, 2017; Elfeky, 2017; Kamel } \\
\text { and Awadallah, 2017; Sarhan et al., } \\
2019\end{array}$ \\
\hline
\end{tabular}

Table 4 shows that an average $42.44 \%$ share of the companies are held by the directors, while the foreign shareholding on average accounts for $2.52 \%$ and the institutional shareholding $17.8 \%$. Thus, we may conclude that the government and business organizations of a transition economy should design policies that attract and compel the institutional investors and foreign investors to optimize their investment decisions. The descriptive statistics of the control variables shows that the size of the company is homogeneous as their standard deviation is only 1.92. Bangladesh is shifting its economy on trade (as developing economies do), their average operating experience is only around 14 years with a standard deviation of around 12 years. It means that the operating experience of the Bangladeshi companies varied a lot. Finally, from the descriptive analysis, a huge variation of profit becomes apparent by showing a standard deviation of $6.81 \%$ with an average profitability of only $4.53 \%$; it represents a very inefficient operating performance by corporate executives. Thus, the government and the business entities should adopt relevant policies to overcome it, and certainly corporate voluntary disclosures may play a pivotal role on this regard (Faisal et al., 2020).

\subsection{Correlation and Multicollinearity Analysis}

Table 5 shows the correlation coefficient of the variables along with their level of significance. The finding reveals that public ownership has inverse relationship with the level of corporate voluntary disclosures with $r=-.569$ at $p \leq .01$. These show that the general shareholding companies are less likely to disclose more voluntary information of the company. However, the directors' ownership has the second highest correlation coefficient with $r=.476$ at $p \leq .01$. This means that the directors' shareholding organizations are proactive to disclose more private information to enhance their reputation towards the owners, which is similar to the findings by Abeysekera and Guthrie (2005). This finding also agrees with both the concept of agency theory as it reduces the conflict between the boards and owners (Jensen $\&$ Meckling, 1976) and the concept of legitimacy theory by providing information to all the stakeholders through legitimizing their roles in the society (Cormier \& Gordon, 2001). Finally, from the correlation matrix, it is apparent that the values for all correlation coefficients are significantly less than .7, thus there is no correlation risk (Tabachnick et al., 2007). 
Table 4: Descriptive statistics

\begin{tabular}{|l|c|c|c|c|c|}
\hline Variables & N & Minimum & Maximum & Mean & Std. deviation \\
\hline VDS & 98 & 9.78 & 63.04 & 29.68 & 12.28 \\
\hline OWN_INS & 98 & .00 & 53.67 & 17.80 & 9.78 \\
\hline OWN_DIR & 98 & .00 & 90.00 & 42.44 & 18.13 \\
\hline OWN_PUB & 98 & 1.11 & 84.73 & 36.49 & 19.09 \\
\hline OWN_FOR & 98 & .00 & 40.79 & 2.52 & 6.49 \\
\hline FIR_LEV & 98 & -1.58 & 19.18 & 1.15 & 2.06 \\
\hline FIR_SIZ & 98 & 14.72 & 25.49 & 21.44 & 1.92 \\
\hline FIR_ROA & 98 & -21.14 & 36.84 & 4.53 & 6.81 \\
\hline FIR_AGE & 98 & 1.00 & 43.00 & 14.38 & 11.67 \\
\hline
\end{tabular}

Table 5: Pearson correlation matrix

\begin{tabular}{|l|c|c|c|c|c|c|c|c|}
\hline & VDS & $\begin{array}{c}\text { OWN_ } \\
\text { INS }\end{array}$ & $\begin{array}{c}\text { OWN_ } \\
\text { DIR }\end{array}$ & $\begin{array}{c}\text { OWN_ } \\
\text { PUB }\end{array}$ & $\begin{array}{c}\text { OWN_ } \\
\text { FOR }\end{array}$ & $\begin{array}{c}\text { FIR_ } \\
\text { LEV }\end{array}$ & $\begin{array}{c}\text { FIR_ } \\
\text { SIZ }\end{array}$ & $\begin{array}{c}\text { FIR } \\
\text { ROA }\end{array}$ \\
\hline OWN_INS & $.143^{* * *}$ & 1 & & & & & & \\
\hline OWN_DIR & $.476^{*}$ & $-.228^{* *}$ & 1 & & & & & \\
\hline OWN_PUB & $-.569^{*}$ & $-.271^{*}$ & $-.735^{*}$ & 1 & & & & \\
\hline OWN_FOR & .043 & .009 & -.032 & $-.310^{*}$ & 1 & & & \\
\hline FIR_LEV & .070 & $-.146^{* * *}$ & $.202^{* *}$ & -.086 & -.072 & 1 & & \\
\hline FIR_SIZ & .090 & $.196^{* *}$ & .094 & $-.181^{* *}$ & $.303^{* * *}$ & .048 & 1 & \\
\hline FIR_ROA & $.240^{*}$ & .046 & $.138^{* *}$ & $-.198^{* *}$ & $.191^{* *}$ & $-.150^{* * *}$ & .060 & 1 \\
\hline FIR_AGE & -.097 & $-.133^{* * *}$ & .106 & .002 & -.022 & $.234^{*}$ & $-.200^{* *}$ & $-.218^{* *}$ \\
\hline
\end{tabular}

* $1 \%$ level of significance

${ }^{* *} 5 \%$ level of significance

*** $10 \%$ level of significance

\subsection{Regression Coefficient and Hypothesis Analysis}

Table 6 summarizes the findings of multiple regression analysis. It postulates that the F statistics is 6.649 at $p<.01$ that reflects the statistical significance of the model. In addition, the adjusted $R^{2}$ is .318 , which implies that the proxy variables of ownership structure explain $31.8 \%$ variation of the corporate voluntary disclosure. From the score of the F statistics and adjusted $R^{2}$ it becomes apparent that the multiple regression model is statistically significant enough to explain the variations of the corporate voluntary disclosures in the transition economy that is Bangladesh. Moreover, Table 6 reconfirmed that we have no multicollinearity since the tolerance value for all proxies of ownership structure is more than .1 (Tabachnick \& Fidell, 2001) and the variance inflation factor is less than 10 (Neter et al., 1983). From the above elements, the multiple regression model has no multicollinearity problems in independent variables and the model may be used with a higher degree of confidence.

The regression coefficient regarding the institutional ownership (OWN_INS) is negative (-.018) and insignificant $(\mathrm{t}=-.122$ and $\mathrm{p}=.903)$ suggesting that institutional shareholding has adverse effect on corporate voluntary disclosure. Indeed, the companies having more institutional shareholders are reluctant to disclose the private information, which mirrors the findings of the literature (Elfeky, 2017; Kolsi, 2017), although Nguyen et al. (2020) found positive relationship between them in Vietnam. We do have the same findings, but no statistical significance. Thus, our first hypothesis is rejected. The coefficient related to directors' ownership has positive (.028) and insignificant $(\mathrm{t}=.127$ and $\mathrm{p}=.899)$ association with the voluntary disclosures. It indicates that the companies having more director shareholdings 
Table 6: Co-efficient of regression

\begin{tabular}{|c|c|c|c|c|c|c|}
\hline & OWN_INS & OWN_DIR & OWN_PUB & OWN_FOR & \multirow{5}{*}{$\begin{array}{l}\text { Adjusted } \\
\text { R-Square }\end{array}$} & \multirow{5}{*}{ F statistics } \\
\hline & Beta & Beta & Beta & Beta & & \\
\hline & (t-Stat) & (t-Stat) & (t-Stat) & (t-Stat) & & \\
\hline & $\begin{array}{c}\text { Tolerance } \\
\text { value }\end{array}$ & Tolerance value & $\begin{array}{c}\text { Tolerance } \\
\text { value }\end{array}$ & Tolerance value & & \\
\hline & VIF value & VIF value & VIF value & VIF value & & \\
\hline $\begin{array}{l}\text { VDS } \\
\text { Beta } \\
\text { (t-Stat) } \\
\text { Tolerance Value } \\
\text { VIF value }\end{array}$ & $\begin{array}{l}-.018 \\
-.122 \\
.342 \\
3.925\end{array}$ & $\begin{array}{l}.028 \\
.127 \\
.145 \\
6.895\end{array}$ & $\begin{array}{l}-.570 * * \\
-2.479 \\
.133 \\
7.512\end{array}$ & $\begin{array}{c}-.162 \\
-1.296 \\
.449 \\
2.229\end{array}$ & $.318^{*}$ & $6.649^{*}$ \\
\hline
\end{tabular}

* $1 \%$ level of significance; ${ }^{* *} 5 \%$ level of significance

tends to disclosure more voluntary information, which is contradictory with the other findings (Sarhan et al., 2019) although ours are not statistical significant. On the contrary, our findings are consistent with those of Donnelly and Mulcahy (2008) and Alnabsha et al. (2018) who obtained no significant association between the directors' shareholding and corporate voluntary disclosures.

Therefore, our hypothesis 2 is rejected. The regression coefficient concerning the public ownership is negative $(-.570)$ and significant $(\mathrm{t}=-2.479$ and $\mathrm{p}=.015)$. Theoretically, the bigger the minority shareholdings, the less likely the influence on the board to get the desired information on the business. Moreover, the minority shareholders typically do not have any private communication with the board, thus have no access to information for taking optimum decisions. Hence, inherently, public ownership has adverse effect on corporate voluntary disclosures due to the less bargaining power. Thus, our third hypothesis is accepted at $p<.05$. The regression coefficient of foreign shareholdings is negative $(-.162)$ and insignificant $(t=-1.296$ and $p=.198)$. The findings mean that foreign ownership has adverse effect on the corporate voluntary disclosures in a transition economy, which is contrary to the findings of some researchers (Aljifri et al., 2014; Kolsi, 2017), although our findings have no statistical significance. In the context of Bangladesh, where the mean of foreign shareholding is only $2.52 \%$, the board has very limited bargain power to compel or induce them to disclose more voluntary information. Thus, our final hypothesis is rejected.

\section{Conclusions and Limitations}

The literature on corporate voluntary disclosures reveals that the influence of ownership structures varies across countries, capital markets, economies, social norms, and practices (Belal et al., 2013; Elfeky, 2017; Kolsi, 2017). Most studies on corporate voluntary disclosures are conducted in developed and developing countries, there is little evidence presented on transition economies (Elfeky, 2017). We have found a significant negative association between public ownership and corporate voluntary disclosures, while we do not find any significant association between corporate voluntary disclosures and institutional ownership, directors' ownership, and foreign ownership. Public or minority shareholding has an inverse relationship with voluntary disclosures as it has less bargaining power to influence the board to disclose more information on the company (Bhuiyan \& Masum, 2010).

The institutional ownership and the foreign ownership have inverse relationship with voluntary disclosures as in Bangladesh many of the business entities have concentrated ownership in the form of family shareholding. Thus, the mean of institutional shareholding is very low (17.8\%) and consequently it is less likely to influence the directors who mostly come from the family shareholdings. However, since the economy of Bangladesh is shifting from the least developing to developing country zone, the entrance and sustenance of foreign investors are not so smooth due to the infrastructure of the country and other policy level assistance of the government (Masum et al., 2019). Although the Bangladeshi government adopted some green policies like green tax, e-Vat act, and digitalization of the countries, these policies are yet to be implemented. In addition, the level of voluntary disclosures is not up to the mark, but the scenario is improving over the years as legislatively, Bangladeshi listed companies have to comply with certain reporting practices prescribed by the securities and exchange commissions (Jahid et al., 2020; Rouf \& Akhtaruddin, 2018). 
The findings of the study have several implications, not only for regulators, policymakers, managers, business entities and prospective investors, but also for all transition economies. Firstly, the business organizations in a transition economy may have less foreign investment and institutional investment. Secondly, the regulatory bodies of Bangladesh may take legislative actions to explore why the disclosure levels of the business entities are below the average, and some good performers can be motivated through rewards. Thirdly, business organizations may have idea of the content of voluntary disclosures that is required to be disclosed to attract and retain both local and foreign investors. Finally, the government of the country may design policies that induce the corporate peoples to disclose more information publicly. There are 22 areas of corporate social responsibility for which corporations may get tax rebate in Bangladesh. The findings may help the government of a transition economy to reshape such policies that will help them on the way of becoming a developing country and sustain over time.

Our study has some limitations. Firstly, like the previous literature, we conducted the study based on a cross-sectional study, thus more robust results on transition economy may be produced through longitudinal studies. Secondly, based on the literature, our disclosure index includes 92 items from nine broad dimensions, which may be country specific, thus may not be generalized to other economies. For instance, disclosing one item is voluntary in Bangladesh, but may not be voluntary in other countries. Thirdly, similar to the other study, we have used only the annual report while the voluntary information of a company can be derived from some other sources like websites, web pages in digital media, etc. Finally, we have used a quantitative approach, but a qualitative approach like interview may provide deeper understanding of the prevailing scenario of corporate reporting in a transition economy such as Bangladesh.

\section{References}

Abeysekera, I., \& Guthrie, J. (2005). An empirical investigation of annual reporting trends of intellectual capital in Sri Lanka. Critical Perspectives on Accounting, 16(3), 151-163.

Akhtaruddin, M., \& Haron, H. (2010). Board ownership, audit committees' effectiveness and corporate voluntary disclosures. Asian Review of Accounting, 18(1), 68-82.

Al-Bassam, W. M., Ntim, C. G., Opong, K. K., \& Downs, Y. (2018). Corporate boards and ownership structure as antecedents of corporate governance disclosure in Saudi Arabian publicly listed corporations. Business \& Society, 57(2), 335-377.

Al Maskati, M., \& Hamdan, A. (2017). Corporate governance and voluntary disclosure: evidence from Bahrain. International Journal of Economics and Accounting, 8(1), 1-28.
Albitar, K. (2015). Firm characteristics, governance attributes and corporate voluntary disclosure: A study of Jordanian listed companies. International Business Research, 8(3), 1-10.

Aljifri, K., Alzarouni, A., Ng, C., \& Tahir, M. I. (2014). The association between firm characteristics and corporate financial disclosures: evidence from UAE companies. The International Journal of Business and Finance Research, 8(2), 101-123.

Alnabsha, A., Abdou, H. A., Ntim, C. G., \& Elamer, A. A. (2018). Corporate boards, ownership structures and corporate disclosures: Evidence from a developing country. Journal of Applied Accounting Research, 19(1), 20-41.

An, Y., Davey, H., \& Eggleton, I. R. (2011). Towards a comprehensive theoretical framework for voluntary IC disclosure. Journal of Intellectual Capital, 12(4), 571-585.

Belal, A. R. (2000). Environmental reporting in developing countries: empirical evidence from Bangladesh. EcoManagement and Auditing: The Journal of Corporate Environmental Management, 7(3), 114-121.

Belal, A. R., Cooper, S. M., \& Roberts, R. W. (2013). Vulnerable and exploitable: The need for organisational accountability and transparency in emerging and less developed economies. Paper presented at the Accounting Forum. Dhaka, Bangladesh.

Bhattacharya, D. (2018). Bangladesh's Graduation from the Least Developed Countries Group: Pitfalls and Promises. Abingdon, UK: Routledge.

Bhuiyan, M., \& Masum, M. (2010). Balanced scorecard: A multistream performance measurement tool for public sector corporations in Bangladesh. The Cost and Management, 38(5), $19-25$.

Bhuyan, M. S. S. (2018). Determinants and Effects of Voluntary Disclosure with a focus on Corporate Governance and Firm Performance: Evidence from Bangladesh. Paper presented at the Accounting Forum. Dhaka, Bangladesh.

Botosan, C. A. (1997). Disclosure level and the cost of equity capital. Accounting Review, 72(3), 323-349.

Branco, M. C., \& Rodrigues, L. L. (2008). Factors influencing social responsibility disclosure by Portuguese companies. Journal of Business Ethics, 83(4), 685-701.

Cormier, D., \& Gordon, I. M. (2001). An examination of social and environmental reporting strategies. Accounting, Auditing \& Accountability Journal, 14(5), 587-617.

Deegan, C. (2002). Introduction: The legitimising effect of social and environmental disclosures-a theoretical foundation. Accounting, Auditing \& Accountability Journal, 15(3), 282311.

Deegan, C., Rankin, M., \& Voght, P. (2000). Firms' disclosure reactions to major social incidents: Australian evidence. Paper presented at the Accounting Forum. Dhaka, Bangladesh.

Dhaliwal, D. S., Li, O. Z., Tsang, A., \& Yang, Y. G. (2011). Voluntary nonfinancial disclosure and the cost of equity capital: 
The initiation of corporate social responsibility reporting. The Accounting Review, 86(1), 59-100.

Donnelly, R., \& Mulcahy, M. (2008). Board structure, ownership, and voluntary disclosure in Ireland. Corporate Governance: An International Review, 16(5), 416-429.

Elango, B., Pattnaik, C., \& Wieland, J. R. (2016). Do business group characteristics matter? An exploration on the drivers of performance variation. Journal of Business Research, 69(9), 3205-3212.

Elfeky, M. I. (2017). The extent of voluntary disclosure and its determinants in emerging markets: Evidence from Egypt. The Journal of Finance and Data Science, 3(1-4), 45-59.

Elmagrhi, M. H., Ntim, C. G., Crossley, R. M., Malagila, J. K., Fosu, S., \& Vu, T. V. (2017). Corporate governance and dividend pay-out policy in UK listed SMEs: The effects of corporate board characteristics. International Journal of Accounting \& Information Management, 25(4), 459-483.

Faisal, F., Situmorang, L. S., Achmad, T., \& Prastiwi, A. (2020). The Role of Government Regulations in Enhancing Corporate Social Responsibility Disclosure and Firm Value. Journal of Asian Finance, Economics and Business, 7(8), 509-518. https:// doi.org/10.13106/jafeb.2020.vol7.no8.509

Ghazali, N. A. M., \& Weetman, P. (2006). Perpetuating traditional influences: Voluntary disclosure in Malaysia following the economic crisis. Journal of International Accounting, Auditing and Taxation, 15(2), 226-248.

Healy, P. M., \& Palepu, K. G. (2001). Information asymmetry, corporate disclosure, and the capital markets: A review of the empirical disclosure literature. Journal of Accounting and Economics, 31(1-3), 405-440.

Hossain, M., Lin, M., \& Adams, M. (1994). Voluntary Disclosure in an Emerging Capital Market: Some Empirical Evidence from Companies Listed on the Kuala. The International Journal of Accounting, 29(3), 334-351.

Islam, M. A., \& Deegan, C. (2008). Motivations for an organisation within a developing country to report social responsibility information. Accounting, Auditing \& Accountability Journal. Dhaka, Bangldesh.

Jahid, M. A., Rashid, M. H. U., Hossain, S. Z., Haryono, S., \& Jatmiko, B. (2020). Impact of Corporate Governance Mechanisms on Corporate Social Responsibility Disclosure of Publicly-Listed Banks in Bangladesh. Journal of Asian Finance, Economics, and Business, 7(6), 61-71. https://doi. org/10.13106/jafeb.2020.vol7.no6.061

Jensen, M. C., \& Meckling, W. H. (1976). Theory of the firm: Managerial behavior, agency costs and ownership structure. Journal of Financial Economics, 3(4), 305-360.

Jiang, H., Habib, A., \& Hu, B. (2011). Ownership concentration, voluntary disclosures and information asymmetry in New Zealand. The British Accounting Review, 43(1), 39-53.

Kamel, H., \& Awadallah, E. (2017). The extent of voluntary corporate disclosure in the Egyptian stock exchange: its determinants and consequences. Journal of Accounting in Emerging Economies, 7(2), 266-291.
Khanna, M., \& Liao, Y. (2014). Globalization and voluntary environmental management in developing countries. Frontiers of Economics in China, 9(1), 138-163.

Khlif, H., Ahmed, K., \& Souissi, M. (2017). Ownership structure and voluntary disclosure: A synthesis of empirical studies. Australian Journal of Management, 42(3), 376-403.

Kolsi, M. C. (2012). The determinants of corporate voluntary disclosure: evidence from the Tunisian capital market. The IUP Journal of Accounting Research and Audit Practices, 11(4), 49-68.

Kolsi, M. C. (2017). The determinants of corporate voluntary disclosure policy: Evidence from the Abu Dhabi Securities Exchange (ADX). Journal of Accounting in Emerging Economies, 7(2), 249-265.

Li, J., Mangena, M., \& Pike, R. (2012). The effect of audit committee characteristics on intellectual capital disclosure. The British Accounting Review, 44(2), 98-110.

Lilienfeld-Toal, U. V., \& Ruenzi, S. (2014). CEO ownership, stock market performance, and managerial discretion. the Journal of Finance, 69(3), 1013-1050.

Lodh, S., Nandy, M., \& Chen, J. (2014). Innovation and Family Ownership: Empirical Evidence from I ndia. Corporate Governance: An International Review, 22(1), 4-23.

Madi, H. K., Ishak, Z., \& Manaf, N. A. A. (2014). The impact of audit committee characteristics on corporate voluntary disclosure. Procedia-Social and Behavioral Sciences, 164, 486-492.

Marston, C., \& Polei, A. (2004). Corporate reporting on the Internet by German companies. International Journal of Accounting Information Systems, 5(3), 285-311.

Masum, M. H., Hassan, N., \& Jahan, T. (2019). Corporate climate change reporting: Evidence from Bangladesh. Accounting \& Management Information Systems/Contabilitate si Informatica de Gestiune, 18(3).

Masum, M. H., \& Khan, M. M. (2019). Impacts of Board Characteristics on Corporate Performance: Evidence from Bangladeshi Listed Companies. International Business and Accounting Research Journal, 3(1), 47-57.

Masum, M. H., Uddin, M. M., Ahmed, H., \& Uddin, M. H. (2019). Corporate Social Responsibility Disclosures And Corporate Performance: Evidence From The Listed Companies in Bangladesh. Academy of Strategic Management Journal, 18(2), 1-16.

Mitchell, J. D., Chia, C. W., \& Loh, A. S. (1995). Voluntary disclosure of segment information: Further Australian evidence. Accounting \& Finance, 35(2), 1-16.

Neter, J., Wasserman, W., \& Kutner, M. H. (1983). Applied linear regression models. Homewood, IL: Richard D. Irwin.

Nguyen, T. M. H., Nguyen, N. T., \& Nguyen, H. T. (2020). Factors Affecting Voluntary Information Disclosure on Annual Reports: Listed Companies in Ho Chi Minh City Stock Exchange. Journal of Asian Finance, Economics, and Business, 7(3), 53-62. https://doi.org/10.13106/jafeb.2020.vol7.no3.53 
Ntim, C. G., \& Soobaroyen, T. (2013). Black economic empowerment disclosures by South African listed corporations: The influence of ownership and board characteristics. Journal of Business Ethics, 116(1), 121-138.

Pillai, R., \& Al-Malkawi, H.-A. N. (2018). On the relationship between corporate governance and firm performance: Evidence from GCC countries. Research in International Business and Finance, 44, 394-410.

Rouf, M. A., \& Akhtaruddin, M. (2018). Factors affecting the voluntary disclosure: a study by using smart PLS-SEM approach. International Journal of Law and Management, 60(6), 1498-1508.

Samaha, K., Khlif, H., \& Hussainey, K. (2015). The impact of board and audit committee characteristics on voluntary disclosure: A meta-analysis. Journal of International Accounting, Auditing and Taxation, 24, 13-28.

Sarhan, A.A., \& Ntim, C. G. (2019). Corporate boards, shareholding structures and voluntary disclosure in emerging MENA economies. Journal of Accounting in Emerging Economies, 9(1), 2-27.

Sarhan, A. A., Ntim, C. G., \& Al-Najjar, B. (2019). Board diversity, corporate governance, corporate performance, and executive pay. International Journal of Finance \& Economics, 24(2), 761-786.

Schadewitz, H. J., \& Blevins, D. R. (1998). Major determinants of interim disclosures in an emerging market. American Business Review, 16(1), 41-44.

Suchman, M. C. (1995). Managing legitimacy: Strategic and institutional approaches. Academy of Management Review, 20(3), 571-610.

Tabachnick, B. G., \& Fidell, L. S. (2001). Principal components and factor analysis. Using Multivariate Statistics, 4(1), 582-633.

Tabachnick, B. G., Fidell, L. S., \& Ullman, J. B. (2007). Using multivariate statistics (Vol. 5). Boston, MA: Pearson.

Trade \& Development. (2019). The least developed countries report 2019: The present and future of external development financeold dependence, new challenges. United Nations Economic and Social Council (UNESC)

Zaini, S. M., Samkin, G., Sharma, U., \& Davey, H. (2018). Voluntary disclosure in emerging countries: a literature review. Journal of Accounting in Emerging Economies, 8(1), 29-65. doi: 10.1108/JAEE-08-2016-0069 